\title{
Anaerobic digested sludge: a new supplementary nutrient source for ethanol production
}

\author{
R. Bashiri ${ }^{1}$ M. Farhadian $^{2}$ - M. A. Asadollahi ${ }^{1}$ A. Jeihanipour ${ }^{1,3}$
}

Received: 5 January 2015/Revised: 19 May 2015/Accepted: 14 December 2015/Published online: 7 January 2016

(C) Islamic Azad University (IAU) 2015

\begin{abstract}
Effluent sludge from an anaerobic digester was used as a source of nitrogen, phosphate, sulfur, and other nutrients in the culture medium of ethanol production by the yeast Saccharomyces cerevisiae. Several pretreatments (mechanical, chemical, thermal, and thermo-chemical) were performed on the anaerobic digested sludge (ADS) to make the nutrients accessible to the yeast cells. Preliminary experiments revealed that $S$. cerevisiae is not able to assimilate the carbon content of the ADS. However, when glucose was added to the medium, ethanol production was observed. The yield of ethanol using untreated ADS was only $10 \%$ of the theoretical yield, but alkaline pretreatment improved it up to $43 \%$. By separating the hydrolysate of alkaline-treated ADS from the suspended solids, the ethanol yield from the supernatant was further improved up to $65 \%$ of theoretical yield. Alkaline-treated ADS exhibited competitive performance with the mixture of yeast extract and mineral salts in ethanol fermentation.
\end{abstract}

Keywords Bioethanol - Anaerobic digested sludge . Sludge management - Pretreatment - Saccharomyces cerevisiae

A. Jeihanipour

azam.jeihanipour@kit.edu

1 Department of Biotechnology, Faculty of Advanced Sciences and Technologies, University of Isfahan, Isfahan 81746-73441, Iran

2 Department of Chemical Engineering, Faculty of Engineering, University of Isfahan, Isfahan 81746-73441, Iran

3 Department of Chemistry and Biosciences, Institute of Chemical Technology and Polymer Chemistry, Karlsruhe Institute of Technology (KIT), Engesserstr. 18, 76131 Karlsruhe, Germany

\author{
Abbreviations \\ AC Acidic pretreatment \\ ADS Anaerobic digested sludge \\ AL Alkaline pretreatment \\ ALTH Combined alkaline and thermal pretreatment \\ CFU Colony forming units \\ PE Pretreatment efficiency \\ SCOD Soluble chemical oxygen demand \\ TCOD Total chemical oxygen demand \\ TDS Total dissolved solids \\ TH Thermal pretreatment \\ TS Total solids \\ UL Ultrasonic pretreatment \\ UNS Untreated sludge \\ WAS Waste activated sludge \\ WWS Wastewater sludge \\ WWTP Wastewater treatment plant
}

\section{Introduction}

Rapid urbanization, especially in the developing countries, and the need for appropriate water and sanitation, necessitated large investments on constructing more wastewater treatment plants $\left(\mathrm{WWTP}_{\mathrm{S}}\right)$ in the last few decades. Activated sludge process is the most widely used process for the treatment of industrial and municipal wastewaters (Motlagh and Goel 2014). In a typical activated sludge process, roughly one-third of the organic carbon from wastewater is converted to waste activated sludge (WAS) (Tchobanoglous et al. 2003). This has caused one of the greatest environmental concerns which come from the accumulation of WAS (Brar et al. 2009) and directed research efforts toward development of new alternative options for either minimization or proper handling of sludge. 
Since WAS contains various nutrients such as carbon, nitrogen, and phosphorous (Tyagi and Lo 2013), utilization of sludge as a replacement for some of the nutrients in the culture media of biological production of value-added products has been investigated as an alternative method (Brar et al. 2009). Thus, biotechnological products such as biopesticides (Yezza et al. 2005), biochemicals such as lactic acid (Ma et al. 2014), and biofuels such as biohydrogen (Ting and Lee 2007) have been produced using WAS as a nutrient source for the involved microorganisms. Cheung and Anderson (1997) tried to produce ethanol from the cellulose content of primary sludge of WWTPs, via simultaneous saccharification and fermentation (SSF). Additionally, using chemical and physical processes, researchers have tried to produce products such as bioplastics (Chua et al. 2003), biofertilizers (Ben Rebah et al. 2007), and biodiesel (Siddiquee and Rohani 2011) from WAS.

Despite all of these researches, anaerobic digestion has remained the dominant large-scale process which is widely applied to transform organic carbon in WAS into methane and reduce the amount of biosolids to be disposed of (Bolzonella et al. 2012, Wang et al. 2014). However, this approach solves the problem only partially. After the anaerobic digestion process, sludge volume and mass are greatly reduced but a new sort of waste, called digestate, is produced which needs further treatment and disposal. It contains biodegradable and recalcitrant organic compounds, pathogens, heavy metals, and other inorganic constituents. However, this sludge can still be considered a source of nutrients and energy, which could be recovered using economically viable approaches. In fact, the digestate has a higher proportion of mineral nitrogen and less decomposable organic matter (Tambone et al. 2010). Nowadays, common treatment technologies to manage this waste are landfilling, combustion, and land application (Zhang et al. 2014).

In many countries, very strict limitations have been set to minimize the disposal of sludge to the landfills due to increasing greenhouse gas emissions $\left(\mathrm{CH}_{4}\right.$ and $\left.\mathrm{CO}_{2}\right)$ and leaching of heavy metals to water and soil from landfills (Kelessidis and Stasinakis 2012). Combustion of sludge is also usually a difficult process due to the high ash and moisture content of ADS (Roy et al. 2011). The potential agricultural use of ADS is also under question because it may result not only in the transfer of resistant bacteria into the environment but also in the propagation of antibiotic resistance genes and have an impact on the bacterial communities of the receiving ecosystem (Calero-Caceres et al. 2014). However, as a matter of fact, after anaerobic digestion of WAS, the produced ADS is still a valuable source of organic carbon, nitrogen, phosphorous, sulfur, as well as some inorganic compounds such as silicates and aluminates, which can be reutilized for value-added production purposes (Zhang et al. 2014).

The hypothesis of the present work was investigating the possibility of utilizing the ADS as an alternate nutrient source for producing bioethanol. Bioethanol is currently the most abundant renewable in the global fuel market which is industrially produced mainly from corn and sugar cane (Soccol et al. 2010). In order to reduce the cost of ethanol production and overcome the "food versus energy" conflict, lots of researchers have focused on finding new carbon source for bioethanol production including agricultural residues and municipal or industrial wastes (Jafari et al. 2011; Jeihanipour and Taherzadeh 2009; Sheikh et al. 2013; Jeihanipour and Bashiri 2015).

For optimum growth of yeast and bioethanol production, yeast extract plus some other synthetic chemicals is often used as a nutrient source in laboratory-scale fermentation (Jeihanipour and Taherzadeh 2009). However, the high cost of this synthetic medium limited its application in industrial process. Thus, new nutrient alternative suitable for bioethanol fermentation is explored by researchers (Asachi et al. 2011). To the best of our knowledge, while this article is being written, there is no scientific report on using ADS as a nutrient source in fermentation processes to produce bioethanol. The ADS is a difficult substrate to be consumed by microorganisms since most of its organic matters have been converted to more complex compounds in the digester (Manara and Zabaniotou 2012). Thus, strong pretreatments are required to break down its structure and release the remained organic matters.

The goal of this study was to investigate the possibility of producing bioethanol by Saccharomyces cerevisiae from the excess sludge of anaerobic digester, produced in a municipal WWTP. However, it was expected and confirmed by preliminary experiments that the carbon content of ADS cannot be consumed by S. cerevisiae. Therefore, the pretreated ADS, enriched by an additional carbon source, i.e., glucose, was used as culture media for production of ethanol via an anaerobic fermentation process. The effect of different treatments and inhibition of sludge on ethanol production were also investigated. 


\section{Materials and methods}

\section{Microorganism and inoculum preparation}

The yeast strain $S$. cerevisiae, CEN.PK113-7D used in this study was grown on agar slants containing (g/l): D-glucose, 20; yeast extract, 10; soy peptone, 20; and agar, 20, at $30{ }^{\circ} \mathrm{C}$ for $36 \mathrm{~h}$ and then maintained at $4{ }^{\circ} \mathrm{C}$ until being used. The inoculum was prepared using fermentation media containing (g/l): D-glucose, 40; $\mathrm{NH}_{4} \mathrm{Cl}, \quad 7.5$; $\mathrm{K}_{2} \mathrm{HPO}_{4}, 3.5 ; \mathrm{MgSO}_{4} \cdot 7 \mathrm{H}_{2} \mathrm{O}, 0.75 ; \mathrm{CaCl}_{2} \cdot 2 \mathrm{H}_{2} \mathrm{O}, 1$; yeast extract, 5. A volume of $25 \mathrm{ml}$ of medium was inoculated by a loopful of the yeast grown on an agar plate and then incubated aerobically at $30^{\circ} \mathrm{C}$ and $180 \mathrm{rpm}$ for $20 \mathrm{~h}$.

\section{Sludge analyses and preparation}

The ADS, used in this study, was obtained from north WWTP of Isfahan, Iran. Upon receiving, it was stored in several $100-\mathrm{ml}$ polypropylene containers, at $-18{ }^{\circ} \mathrm{C}$, and prior to use, the wet ADS was thawed and sterilized at $121^{\circ} \mathrm{C}$ for $30 \mathrm{~min}$.

\section{Sludge pretreatment}

In order to release nutrients exist in the ADS suspended solids, various pretreatments including acid hydrolysis (AC), alkaline hydrolysis (AL), thermal hydrolysis (TH), ultrasonication (UL), and the combination of alkaline and thermal hydrolysis (ALTH) were applied and their efficiency was compared.

Acid (AC) or alkaline (AL) pretreatments were conducted on $25 \mathrm{ml}$ of sterilized ADS in glass bottles at a $\mathrm{pH}$ of 2 or 11 by the aid of a few drops of $1 \mathrm{~N} \mathrm{H}_{2} \mathrm{SO}_{4}$ or $\mathrm{NaOH}$ solution, respectively, followed by incubation at $37{ }^{\circ} \mathrm{C}$ for $2 \mathrm{~h}$.

Thermal pretreatment $(\mathrm{TH})$ was also carried out on the sterilized ADS, in an autoclave for $1 \mathrm{~h}$ at $121^{\circ} \mathrm{C}$ (Barjenbruch and Kopplow 2003).

The ultrasonic pretreatment (UL) was performed using a 300-W sonication apparatus (Hielscher UP200S, Teltow, Germany) with a probe diameter of $14 \mathrm{~mm}$. The sonication was carried out at room temperature for $1 \mathrm{~h}$ (Pham et al. 2009) while the probe was immersed $2 \mathrm{~cm}$ into $25 \mathrm{ml}$ of sterilized ADS in a 50-ml falcon tube.

The combination of alkaline and thermal pretreatment (ALTH) was performed on $25 \mathrm{ml}$ of ADS in a 50-ml bottle the same as mentioned above. The alkaline treatment was performed prior to the thermal treatment.
The $\mathrm{pH}$ of all pretreated samples was adjusted at $7 \pm 0.5$ by the aid of a few drops of $1 \mathrm{~N} \mathrm{H}_{2} \mathrm{SO}_{4}$ or $\mathrm{NaOH}$ solution, and then they were sterilized for $20 \mathrm{~min}$ at $121{ }^{\circ} \mathrm{C}$ to be prepared for inoculation.

The pretreatment efficiency (PE) was calculated using Eq. (1) (Foladori et al. 2010):

$\mathrm{PE}=\frac{\left(\mathrm{SCOD}-\mathrm{SCOD}_{0}\right)}{\left(\mathrm{TCOD}-\mathrm{SCOD}_{0}\right)} \times 100$

$S C O D$ soluble chemical oxygen demand of pretreated sludge (mg/l); $S C O D_{0}$ soluble chemical oxygen demand of untreated sludge $(\mathrm{mg} / \mathrm{l}) ; T C O D$ total chemical oxygen demand of untreated sludge $(\mathrm{mg} / \mathrm{l})$.

\section{Aerobic fermentation}

In order to determine the biomass production ability of $S$. cerevisiae using nutrients of the ADS, aerobic cultivation was performed. Pretreated or untreated ADS was mixed with deionized water (final solid concentration of $10 \mathrm{~g} / \mathrm{l}$ ) and glucose solution (final glucose concentration of $40 \mathrm{~g} / \mathrm{l}$ ). The samples were then inoculated by $S$. cerevisiae inocu$\operatorname{lum}(4 \% \mathrm{v} / \mathrm{v})$, making an initial cell concentration of about $6 \times 10^{5} \mathrm{cell} / \mathrm{ml}$, followed by incubation at $30^{\circ} \mathrm{C}$ and $180 \mathrm{rpm}$ for $20 \mathrm{~h}$. The cell concentration of S. cerevisiae before and after incubation was measured using the colony-forming units (CFU) method. The growth ability was calculated based on the initial $\left(X_{0}\right)$ and final $(X)$ viable yeast cells in the culture (Eq. 2).

Growth ability $=X / X_{0}$

\section{Anaerobic fermentation}

Anaerobic fermentation was carried out in batch glass bottles (working volume of $25 \mathrm{ml}$ ) with butyl rubber seals and aluminum caps. A volume of $5.2 \mathrm{ml}$ of pretreated or untreated sludge was mixed with deionized water (final sludge solid concentration of $10 \mathrm{~g} / \mathrm{l})$ and glucose solution (final glucose concentration of $40 \mathrm{~g} / \mathrm{l}$ ), and then the bottles were sealed and sparged with pure nitrogen gas for $10 \mathrm{~min}$ to provide anaerobic condition (Jeihanipour et al. 2010). The bottles were sterilized at $121{ }^{\circ} \mathrm{C}$ for $20 \mathrm{~min}$, inoculated ( $4 \% \mathrm{v} / \mathrm{v}$ resulting in an initial yeast cells concentration of about $10^{6}$ cells $/ \mathrm{ml}$ ), and then incubated at $30^{\circ} \mathrm{C}$ and $180 \mathrm{rpm}$ for 2 days. Samples were withdrawn every $12 \mathrm{~h}$ for glucose and ethanol analyzes. While sampling, the extra pressure due to produced $\mathrm{CO}_{2}$ inside bottles was released. The percentage of theoretical yield of ethanol was calculated using Eq. (3): 
Percentage of theoretical yield of ethanol

$$
=\frac{\frac{g \text { Produced ethanol }}{g \text { Initial glucose }}}{\text { Theoretical yield of ethanol }} \times 100
$$

The theoretical yield of ethanol from glucose is $0.51 \mathrm{~g}$ ethanol/g glucose.

It should be noted that, since it is well known that $S$. cerevisiae is only able to consume six-carbon sugars, glucose (40 g/l) was added to ADS as a carbon source in all the experiments. However, the capability of the microorganism for converting the carbon content of the pretreated and untreated ADS into ethanol under anaerobic condition was examined.

Moreover, in order to investigate the effect of total solids of ADS on ethanol production and evaluate its inhibitory effect toward S. cerevisiae, three sets of fermentations were performed. In the first series, treated ADS with a final solid concentration of $10 \mathrm{~g} / \mathrm{l}$ was added to the fermentation media containing (g/l): D-glucose, $40 ; \mathrm{NH}_{4} \mathrm{Cl}$, 7.5; $\mathrm{K}_{2} \mathrm{HPO}_{4}, 3.5 ; \mathrm{MgSO}_{4} \cdot 7 \mathrm{H}_{2} \mathrm{O}, 0.75 ; \mathrm{CaCl}_{2} \cdot 2 \mathrm{H}_{2} \mathrm{O}, 1$; yeast extract, 5. The result was compared to the media without sludge, called control sample. In the second series, different concentration of treated $\operatorname{ADS}(0,5,10$, and $30 \mathrm{~g} / \mathrm{l}$ solid concentration) was added to glucose solution (final glucose concentration of $40 \mathrm{~g} / \mathrm{l}$ ) and then inoculated to investigate the effect of total solid concentration of sludge on fermentation. In the third one, the liquid phase and solid phase of treated ADS were separated by centrifuging at $4000 \mathrm{rpm}$ for $20 \mathrm{~min}$ and used as a supplementary nutrient in ethanol fermentation.

\section{Analysis methods}

In order to identify the amount of total carbon, hydrogen, nitrogen, and sulfur of the ADS, it was dried at $70{ }^{\circ} \mathrm{C}$ and then ground by a household mill (Moulinex ${ }^{\mathrm{TM}}$ ). The dried ADS was analyzed by a CHNS analyzer (LECO 923, LECO, MI, USA). Moreover, total solids, volatile solids, fixed solids, total dissolved solids, phosphorous $\left(\mathrm{PO}_{4}{ }^{3-}\right)$, ammonium nitrogen $\left(\mathrm{NH}_{4}{ }^{+}-\mathrm{N}\right)$, and chemical oxygen demand (COD) were determined according to the APHA standard methods (Rice et al. 2012). The heavy metals analysis was performed using a Flame Atomic Absorption Spectrometer (Varian 220 FS, Varian, Palo Alto, CA).

The liquid samples taken from the fermentation media were analyzed after centrifugation at $10,000 \mathrm{rpm}$ for $10 \mathrm{~min}$. The ethanol concentration was measured by a gas chromatograph (Agilent $6890 \mathrm{~N}$, Agilent Technologies Inc., CA, USA) equipped with an FID detector. Analytes were separated on an HP-INNOWAX column (60 $\mathrm{m} \times 0.32 \mathrm{~mm}$ i.d., $0.5 \mu \mathrm{m}$ film thickness). The carrier gas was nitrogen with a flow rate of $3.3 \mathrm{~mm} / \mathrm{min}$. The detector and injector temperatures were set at $200{ }^{\circ} \mathrm{C}$ and $160{ }^{\circ} \mathrm{C}$, respectively. The initial oven temperature was adjusted at $60{ }^{\circ} \mathrm{C}$. The oven temperature was increased to $80{ }^{\circ} \mathrm{C}$ at a ramp of $10^{\circ} \mathrm{C} / \mathrm{min}$ and then to $150{ }^{\circ} \mathrm{C}$ at a rate of $60{ }^{\circ} \mathrm{C} / \mathrm{min}$. The oven temperature was held at $150{ }^{\circ} \mathrm{C}$ for $1 \mathrm{~min}$.

All experiments were performed at least in duplicate, and the results are presented as averages with deviations of less than $7.0 \%$.

\section{Results and discussion}

\section{Characterization of the ADS}

The physicochemical properties of the ADS, used in this study, are shown in Table 1. The $\mathrm{pH}$ of the ADS was around 8.0, and its total solids (TS) and total dissolved solids (TDS) were 48.5 and $5.0 \mathrm{~g} / \mathrm{l}$, respectively. Therefore, the suspended solids could be estimated as $43.5 \mathrm{~g} / \mathrm{l}$. Volatile solids and fixed solids concentrations were measured as 24.3 and $25.0 \mathrm{~g} / \mathrm{l}$, respectively. Besides, CHNS analysis showed that the ADS consists of $31 \%$ carbon, $5 \%$ hydrogen, $4 \%$ nitrogen, and $1 \%$ sulfur. Total ammonia-nitrogen and phosphorous as $\mathrm{PO}_{4}{ }^{3-}$ were also measured as 573.3 and $657.1 \mathrm{mg} / \mathrm{l}$, respectively (Table 1). Additionally, the most abundant heavy metals in the ADS were Fe (10,900 mg/l), Zn (550 mg/l), Cu (290 mg/l), and Mn $(200 \mathrm{mg} / \mathrm{l})$, whereas the concentrations of $\mathrm{Pb}(73 \mathrm{mg} /$ 1), Ni (34 mg/l), Cr (35 mg/l), and Cd (1 mg/l) were not high, compared to the sludge analyzed in other studies (Table 2). Total chemical oxygen demand (TCOD) was also measured as 18,262 mg/l of which $7066 \mathrm{mg} / \mathrm{l}$ was in soluble form (Table 1).

\section{Pretreatments efficiency in releasing the nutrients of the ADS}

In order to release the organic matters of ADS, several pretreatments (mechanical, chemical, thermal, and thermochemical) were performed. The pretreatment efficiency (PE), a criterion of efficiency of the treatment to increase the soluble COD, was calculated using Eq. (1). The results are shown in Table 3. The amount of $\mathrm{NH}_{4}{ }^{+}-\mathrm{N}$ and $\mathrm{PO}_{4}{ }^{3-}$ measured after pretreatments are also presented in this table. Most of the enhancement was obtained after ALTH and UL treatment with pretreatment efficiency of $66.9 \%$ and $37.4 \%$, respectively. The $\mathrm{TH}, \mathrm{AC}$, and $\mathrm{AL}$ treatments could also solubilize $21.7,16.7$, and $16.4 \%$ of COD, respectively. Besides, ALTH could release more 
Table 1 Physicochemical characteristics of ADS

Table 2 Comparison of heavy metals content of ADS of Isfahan wastewater treatment plant with the sludge of other countries

\begin{tabular}{lrlr}
\hline Physical characteristics & \multicolumn{1}{l}{ ADS } & Chemical characteristics & \multicolumn{1}{c}{ ADS } \\
\hline Total solids $(\mathrm{g} / \mathrm{l})$ & $48.50 \pm 0.71$ & Total carbon $(\%)$ & $30.85 \pm 0.08$ \\
Total dissolved solid $(\mathrm{g} / \mathrm{l})$ & $5.00 \pm 0.05$ & Total nitrogen $(\%)$ & $3.47 \pm 0.01$ \\
Total suspended solids $(\mathrm{g} / \mathrm{l})$ & $43.50 \pm 0.71$ & Total hydrogen $(\%)$ & $4.73 \pm 0.00$ \\
Volatile solids $(\mathrm{g} / \mathrm{l})$ & $24.34 \pm 0.94$ & Total sulfur $(\%)$ & $0.76 \pm 0.04$ \\
Fixed solids $(\mathrm{g} / \mathrm{l})$ & $25.00 \pm 0.94$ & Ammonia nitrogen $(\mathrm{mg} / \mathrm{l})$ & $573.34 \pm 0.05$ \\
pH & $7.93 \pm 0.08$ & Phosphorous as $\mathrm{PO}_{4}{ }^{3-}(\mathrm{mg} / \mathrm{l})$ & $657.14 \pm 0.05$ \\
& & COD $(\mathrm{mg} / \mathrm{l})$ & $18.260 \pm 10$ \\
& & SCOD $(\mathrm{mg} / \mathrm{l})$ & $7.070 \pm 8$ \\
\hline
\end{tabular}

\begin{tabular}{lccl}
\hline $\begin{array}{l}\text { Heavy } \\
\text { metal }\end{array}$ & $\begin{array}{l}\text { ADS used in this } \\
\text { study }(\mathrm{mg} / \mathrm{l})\end{array}$ & $\begin{array}{l}\text { ADS in Denmark (mg/l) } \\
\text { (Xiang et al. 2000) }\end{array}$ & $\begin{array}{l}\text { ADS in Hong Kong (mg/l) } \\
\text { (Marchioretto et al. 2002) }\end{array}$ \\
\hline $\mathrm{Fe}$ & 10,900 & $18,800-24,500$ & 72,200 \\
$\mathrm{Zn}$ & 550 & $1320-2320$ & 2823 \\
$\mathrm{Cu}$ & 290 & $745-1050$ & 255 \\
$\mathrm{Mn}$ & 200 & $280-420$ & - \\
$\mathrm{Pb}$ & 73 & $185-205$ & 57 \\
$\mathrm{Cr}$ & 34 & $345-495$ & 663 \\
$\mathrm{Ni}$ & 35 & $20-40$ & 622 \\
$\mathrm{Cd}$ & 1 & $2-3$ & - \\
\hline
\end{tabular}

\begin{tabular}{lllll}
\hline Pretreatment & $\mathrm{PE}^{\mathrm{a}}(\%)$ & $\mathrm{NH}_{4}{ }^{+}-\mathrm{N}(\mathrm{mg} / \mathrm{l})$ & $\mathrm{PO}_{4}{ }^{3-}(\mathrm{mg} / \mathrm{l})$ & Growth ability $^{\mathrm{b}}$ \\
\hline $\mathrm{ALTH}$ & 66.9 & $513.34 \pm 0.05$ & $517.86 \pm 0.05$ & $\mathrm{Na}^{\mathrm{c}}$ \\
$\mathrm{AL}$ & 16.4 & $420.00 \pm 0.05$ & $507.14 \pm 0.05$ & 19.9 \\
$\mathrm{AL}^{\mathrm{d}}$ & 16.4 & $420.00 \pm 0.05$ & $507.14 \pm 0.05$ & 0.35 \\
$\mathrm{TH}$ & 21.7 & $\mathrm{Na}$ & $\mathrm{Na}$ & 17.2 \\
$\mathrm{AC}$ & 16.7 & $\mathrm{Na}$ & $\mathrm{Na}$ & 12.1 \\
$\mathrm{UL}$ & 37.4 & $\mathrm{Na}$ & $\mathrm{Na}$ & 0.4 \\
$\mathrm{UNS}$ & - & $373.34 \pm 0.05$ & $457.14 \pm 0.05$ & 8.5 \\
\hline
\end{tabular}

Table 3 Efficiency of different pretreatments (PE) on ADS and the amount of $\mathrm{NH}_{4}{ }^{+}-\mathrm{N}$ and $\mathrm{PO}_{4}{ }^{3-}$ released after each pretreatment and the growth ability of $S$. cerevisiae on pretreated and untreated ADS

\footnotetext{
${ }^{a}$ Calculated using Eq. (1)

b Calculated using Eq. (2)

c Not analyzed

${ }^{\mathrm{d}}$ Cultivation without glucose
}

ammonia-nitrogen and phosphorous, i.e., 513.3 and $517.9 \mathrm{mg} / \mathrm{l}$, respectively, in comparison with AL treatment which released $420.0 \mathrm{mg} / \mathrm{l} \mathrm{NH}_{4}{ }^{+}-\mathrm{N}$ and $507.1 \mathrm{mg} / \mathrm{l}$ $\mathrm{PO}_{4}{ }^{3-}$. This method of analysis and formula of calculation of PE are usually used to evaluate the effect of a treatment on excess activated sludge followed by anaerobic digestion to reduce the sludge volume (Foladori et al. 2010). Therefore, measuring the released COD can somehow predict whether the pretreatment has been effective to increase the yield of methane; however, this COD cannot necessarily be consumed by an ethanol producer microorganism like $S$. cerevisiae.

\section{Aerobic growth of $S$. cerevisiae on ADS and the effect of pretreatment}

In order to investigate the growth ability of S. cerevisiae on the ADS, a cultivation medium consisted of glucose as carbon source and pretreated or untreated ADS (UNS) as the source of supplementary nutrients was used and the 
growth ability was calculated using Eq. (2). Whereas the growth ability of $S$. cerevisiae on the UNS was only 8.5, $\mathrm{AL}, \mathrm{TH}$, and $\mathrm{AC}$ treatments significantly increased the growth ability of $S$. cerevisiae to 19.9, 17.2, and 12.1, respectively. However, ultrasonication of $\mathrm{ADS}$ led to a significantly lower growth ability of $S$. cerevisiae, i.e., 0.4, compared to the UNS (Table 3). These results confirmed that with the help of a suitable pretreatment, ADS could be considered as a promising substitute nutrient for yeast extract and other synthetic nutrients in cultivation media of S. cerevisiae.

\section{Effect of pretreatment of ADS on the ethanol yield of $S$. cerevisiae}

Since the easy-to-digest nutrients exist in the sludge used in the present study have already been consumed during biological processes taking place inside the digester, performing an appropriate pretreatment on the sludge is a key factor in releasing the nutrients and making them accessible for the microorganisms.

After $48 \mathrm{~h}$ of fermentation, the ethanol yield in the control was obtained as $84 \%$ of the theoretical yield (Fig. 1). At the same condition, the AL and ALTH treatment led to the highest ethanol yield, i.e., 43 and $33 \%$ of the theoretical yield, respectively, while the $\mathrm{AC}, \mathrm{TH}$, and UL treatment and UNS resulted in a lower ethanol yield of $16,3,2$, and $10 \%$ of the theoretical yield, respectively (Fig. 1).

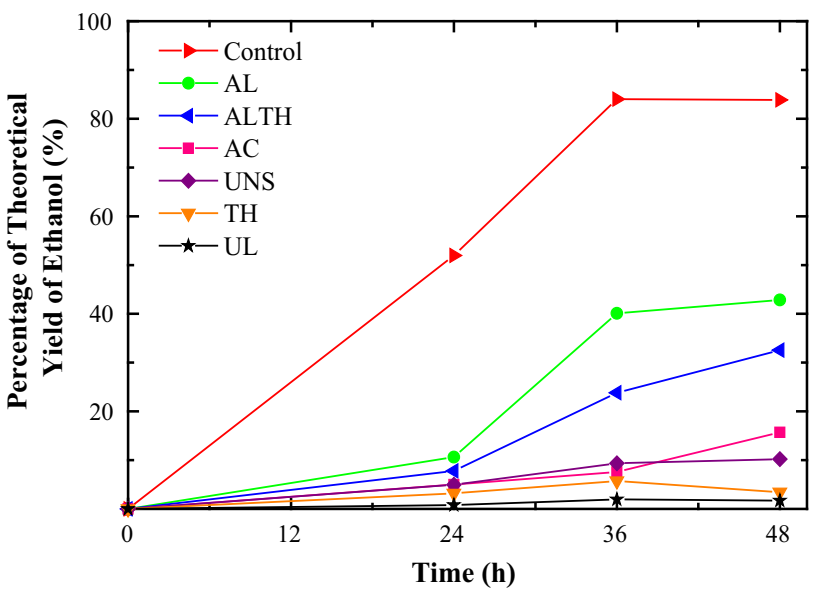

Fig. 1 Ethanol yield (as a percentage of the theoretical yield) for the treated ADS (total solid concentrations of $10 \mathrm{~g} / \mathrm{l}$ ) and control sample during $48 \mathrm{~h}$ of fermentation
On the other hand, although the amount of soluble oxygen demand after ALTH and also UL was significantly higher than that achieved by $\mathrm{AC}, \mathrm{TH}$, and $\mathrm{AL}$ treatments (Table 3), the ethanol yield was the highest for the AL treatment and the least for the one treated by UL (Fig. 1). These conflicting results can be explained by considering the pretreatment mechanisms. There are several studies indicating the possibility of heavy metal solubilization after acid hydrolysis of sludge (Babel and del Mundo Dacera 2006), which might adversely affect the growth of microorganisms (Wang and Chen 2006) and ethanol yield.

The ion $\mathrm{Fe}^{2+}$ has been shown having mutagenic effect on the $S$. cerevisiae. Indeed, excess free iron has the potential to disrupt cellular processes through several mechanisms such as participating in oxidation-reduction chemistry inside the cell, leading to generation of hydroxyl radicals and other reactive oxygen species (Philpott et al. 1998). Besides, $\mathrm{Mn}^{2+}$ can cause a significant reduction in the biomass yield of S. cerevisiae (Blackwell et al. 1998). Therefore, with respect to the heavy metal content of the utilized sludge in the present study (Table 2), it can be concluded that acidic pretreatment could solubilize these heavy metal ions and subsequently, negatively affect yeast growth and ethanol production.

In the case of thermal treatment, which results in cell degradation, the intracellular content is released and some chemical and physical reactions occur between them, causing the formation of inhibitory intermediate compounds and recalcitrant (Wilson and Novak 2009). At high temperatures, carbohydrates and released amino acids get involved into maillard reactions leading to the formation of melanoidine, which are extremely recalcitrant compounds (Carrère et al. 2010). The thermal treatment done in this study might have resulted in toxic compounds formation and the reduction of ethanol yield consequently. However, when thermal process is combined by alkaline treatment, these negative effects are reduced considerably, making the ALTH a second candidate for the highest ethanol yield in comparison with the stand-alone AL. This result is in accordance with other findings, suggesting AL and ALTH being the best ones for solubilizing the nutrients of sludge (Yan et al. 2013).

The contradictory results in COD solubilization and ethanol yield for the UL might also be due to the potential of the ultrasound waves in releasing the $\mathrm{Mg}^{2+}$ and $\mathrm{Ca}^{2+}$ ions existing among the extracellular polymeric substances, the main component of ADS (Pilli et al. 2011). Indeed, the microorganism growth rate might have been negatively affected by these ions. 


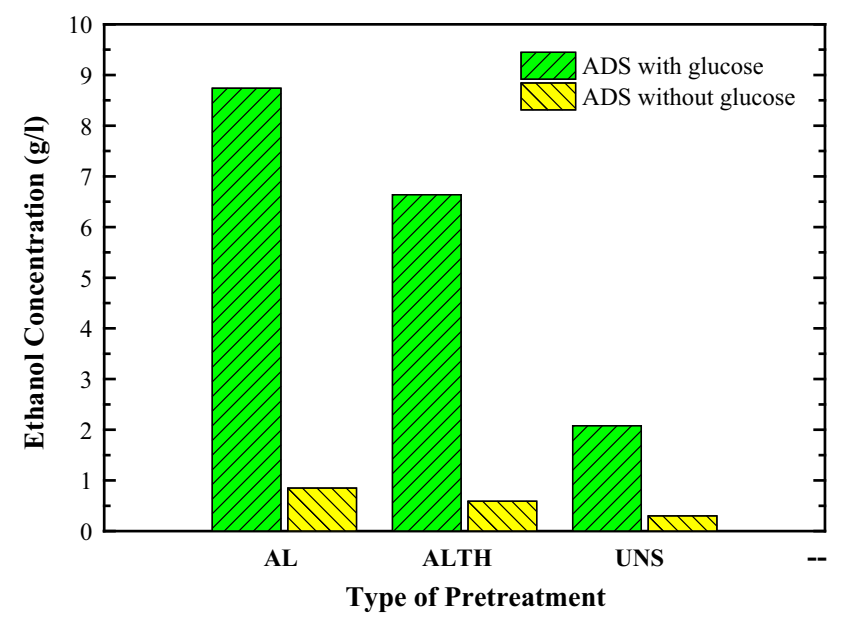

Fig. 2 Ethanol concentration for the pretreated and untreated ADS (total solid concentrations of $10 \mathrm{~g} / \mathrm{l}$ ) with and without glucose after $48 \mathrm{~h}$ of fermentation

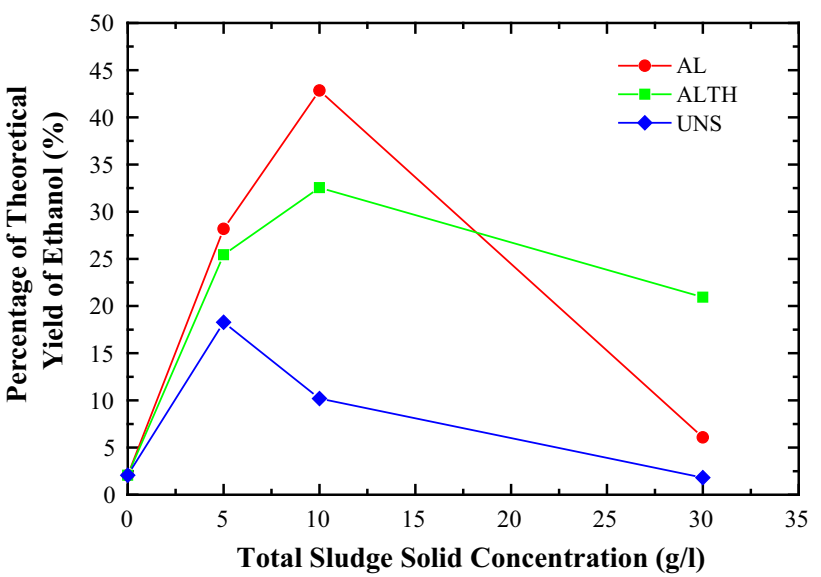

Fig. 3 Ethanol yield (as a percentage of the theoretical yield) for pretreated and untreated ADS containing different total solid concentrations after $48 \mathrm{~h}$ of fermentation

\section{Importance of the presence of both glucose and ADS in the media of fermentation}

In the absence of glucose, after $48 \mathrm{~h}$ of fermentation, the concentration of ethanol in the mediums containing $10 \mathrm{~g} / \mathrm{l}$ total solid of AL- and ALTH-treated ADS was obtained as 0.8 and $0.6 \mathrm{~g} / \mathrm{l}$, respectively (Fig. 2), while by adding $40 \mathrm{~g} /$ 1 glucose to the medium the ethanol concentration at the same conditions was increased to 8.7 and $6.6 \mathrm{~g} / \mathrm{l}$, respectively (Fig. 2). In the case of UNS, the concentration of ethanol after $48 \mathrm{~h}$ fermentation was 0.3 and $2.1 \mathrm{~g} / \mathrm{l}$, with no glucose and with $40 \mathrm{~g} / 1$ glucose, respectively. These results showed that neither the pretreated ADSs nor the untreated one led to a considerable accumulation of ethanol in the absence of glucose. Therefore, for the rest of the experiments, glucose as a carbon source was added to the culture medium and the ADS served as a source of nutrients other than carbon. This result was in accordance with other works of literature (Ma et al. 2014; Kobayashi et al. 2005).

In addition to this, in order to convey the significance of ADS on ethanol yield, S. cerevisiae was inoculated to a sludge-free medium, consisted of only glucose and water under anaerobic condition. It can be inferred from Fig. 3 that when total solid of sludge was 0 , the ethanol concentration was negligible (nearly $2 \%$ of theoretical yield). In fact, this minimal yield is obtained as a result of nutrients within the inoculum itself. In other words, ethanol production depends highly on the presence of other nutrients as well as glucose, which is merely supplied by ADS in this study.

\section{Effect of total solids of ADS on ethanol production}

Three sets of experiments were performed to study the inhibitory effect of total solid content of ADS on the production of ethanol. In the first series, a standard synthetic media, i.e., the mineral salts solution used in inoculum preparation with a glucose concentration of $40 \mathrm{~g} / \mathrm{l}$, was supplemented with $10 \mathrm{~g} / \mathrm{l}$ total solid of AL- and ALTHtreated ADS to examine the effect of sludge on the efficiency of ethanol production by yeast. The results showed that the ALTH-treated ADS has no inhibitory effect on ethanol production and the yield, i.e., $86 \%$ of theoretical yield, is similar to the ethanol yield of the control medium containing no sludge (Table 4). However, the addition of $10 \mathrm{~g} / \mathrm{l}$ of AL-treated sludge reduced the ethanol yield up to $64 \%$ of theoretical yield (Table 4). Therefore, it can be concluded that ALTH treatment reduced the inhibitory effect of ADS but produced fewer nutrients, consumable by S. cerevisiae, compared to the AL treatment.

The second set was designed to compare ethanol yields at different total solid concentrations (i.e., 0, 5, 10, and $30 \mathrm{~g} / \mathrm{l}$ ) of ADS. In the cultivation medium, besides sludge,
Table 4 Comparison of ethanol yield (as a percentage of theoretical yield) for the solid phase and liquid phase of ADS as the only supplementary nutrient sources and also ADS supplemented with mineral salts

\begin{tabular}{llll}
\hline Pretreatment & \multicolumn{2}{l}{ Yield of ethanol after $48 \mathrm{~h}$ fermentation (\% of theoretical yield) } \\
\cline { 2 - 4 } & Liquid phase of ADS & Solid phase of ADS & ADS + Mineral salts + Glucose \\
\hline ALTH & 62.54 & 10.15 & 85.54 \\
AL & 65.49 & 8.28 & 63.53 \\
Control & - & - & 83.87
\end{tabular}


there was $40 \mathrm{~g} / \mathrm{l}$ glucose. Data presented in Fig. 3 reveal that for untreated ADS, total solid concentration higher than $5 \mathrm{~g} / \mathrm{l}$ causes inhibitory effect, while for AL- and ALTH-treated sludge the inhibitory effect was observed at total solid concentrations of above $10 \mathrm{~g} / \mathrm{l}$. Therefore, there is an optimum level for the total solids of sludge for ethanol production, which may change depending on the employed treatment. This was in accordance with other literature (Vidyarthi et al. 2002).

In the third series of the experiments, the solid phase of ALTH- and AL-treated ADS was separated from the liquid phase and both were separately tested as nutrient sources for ethanol production (Table 4). When only solid part of the ALTH- and AL-treated ADS was used, the ethanol yield of 10 and $8 \%$ of the theoretical yield was respectively obtained (Table 4). However, supplementing the media with the supernatant of those sludges resulted in, respectively, 63 and $65 \%$ of the theoretical yield of ethanol after $48 \mathrm{~h}$ of fermentation. The solid particles may exhibit inhibitory effects on the growth and ethanol production by aggregating and slowing down the transport of nutrients to the cell (de Lourdes Tirado Montiel et al. 2001). Thus, the whole process can be improved by using the supernatant of pretreated sludge. This is because the released nutrients are more likely to transfer to the microorganism due to the unanimous medium provided by the supernatant.

\section{Economic perspective}

There is a lack of data for economic evaluation of ADSbased ethanol in the litrature since no one has so far used ADS as a supplementary nutrient source for ethanol production. However, in some articles, second-generation ethanol from lignocellulosic residues is investigated from this point of view (Macrelli et al. 2012). For instance, by targeting the ethanol production of 451 per dry ton of sugarcane and estimating the costs as follows: enzymes (0.341 US $\$ / 1)$, acid (0.08 US $\$ / 1)$, base (0.02 US $\$ / 1)$, water consumption (0.045 US \$/l), vinasse sales ( -0.003 US $\$ / 1)$, labor, maintenance, and insurance (0.148 US \$/l), electricity $(0.357$ US $\$ / 1)$, and capital cost $(0.56$ US $\$ / 1)$, the minimum ethanol selling price would be calculated as 1.548 US $\$ / 1$ (Macrelli et al. 2012). Although this estimation contains the cost of pretreatments in which either of chemicals or energy is required, the price of other nutrients such as yeast extract and synthetic salts which can increase the costs substantially is not included. Therefore, it is obvious that by replacing ADS as a nutrient supplementary source, the final selling price of ethanol would decline considerably. Moreover, by integrating the ADS-based ethanol plant with WWTPs, it is possible to reduce the disposal costs of ADS as well as its environmental risks.

\section{Conclusion}

In the present study, the digested sludge (ADS), an unavoidable by-product of the WWTPs, was used as a supplementary nutrient to replace yeast extract and other nutrients, i.e., mineral salts, in fermentation media of ethanol production. Besides, this could be a more sustainable option in sludge management via using ADS nutrients in biological production of value-added products (Brar et al. 2009). The obtained results showed that the order of pretreatment efficiency to increase the ethanol yield was $\mathrm{AL}>\mathrm{ALTH}>\mathrm{AC}>\mathrm{TH}>\mathrm{UNS}>\mathrm{UL}$. It is worth reminding that apart from the sludge in the media, there were only glucose and water. In other words, in one liter of culture media, $5 \mathrm{~g}$ yeast extract plus 12.75 grams other nutrient chemicals was replaced by $206 \mathrm{ml}$ ADS containing 10 grams total solid, and finally, around $10 \mathrm{~g}$ ethanol $(0.25 \mathrm{~g} / \mathrm{g}$ glucose $)$ was produced after AL treatment of ADS. This result is very promising and could be improved further by optimizing the pretreatment parameters and fermentation conditions. Moreover, there is an optimum point for sludge with different total solid concentrations depending on the pretreatment type. For instance, while the concentration of $10 \mathrm{~g} / \mathrm{l}$ was obtained as an optimum point for $\mathrm{AL}$ and $\mathrm{ALTH}$, the optimum point of $5 \mathrm{~g} / \mathrm{l}$ was gained for UNS. Besides, the results showed that the supernatant of ALTH- and AL-treated ADS has a better potential for ethanol production in comparison with its solid phase and can improve the ethanol yield up to 63 and $65 \%$ of the theoretical yield, respectively.

Acknowledgments The authors appreciate the Water and Wastewater Company of Isfahan Province (Iran) for their financial support of the present study.

\section{References}

Asachi R, Karimi K, Taherzadeh MJ (2011) Fungal autolysate as a nutrient supplement for ethanol and chitosan production by Mucor indicus. Biotechnol Lett 33:2405-2409

Babel S, del Mundo Dacera D (2006) Heavy metal removal from contaminated sludge for land application: a review. Waste Manage 26:988-1004 
Barjenbruch M, Kopplow O (2003) Enzymatic, mechanical and thermal pre-treatment of surplus sludge. Adv Environ Res 7:715-720

Blackwell K, Tobin J, Avery S (1998) Manganese toxicity towards Saccharomyces cerevisiae: dependence on intracellular and extracellular magnesium concentrations. Appl Microbiol Biotechnol 49(6):751-757

Bolzonella D, Cavinato C, Fatone F, Pavan P, Cecchi F (2012) High rate mesophilic, thermophilic, and temperature phased anaerobic digestion of waste activated sludge: a pilot scale study. Waste Manage 32:1196-1201

Brar S, Verma M, Tyagi R, Surampalli R (2009) Value added products from wastewater sludge: a road to sustainability. In: Tyagi R, Surampalli R, Yan S, Zhang T, Kao C, Lohani B (eds) Sustainable sludge management. ASCE Publications, Reston, pp 37-65

Calero-Caceres W, Melgarejo A, Colomer-Lluch M, Stoll C, Lucena F, Jofre J, Muniesa M (2014) Sludge as a potential important source of antibiotic resistance genes in both the bacterial and bacteriophage fractions. Environ Sci Technol 48:7602-7611

Carrère H, Dumas C, Battimelli A, Batstone D, Delgenes J, Steyer J, Ferrer I (2010) Pretreatment methods to improve sludge anaerobic degradability: a review. J Hazard Mater 183(1):1-15

Cheung SW, Anderson BC (1997) Laboratory investigation of ethanol production from municipal primary wastewater solids. Bioresour Technol 59:81-96

Chua AS, Takabatake H, Satoh H, Mino T (2003) Production of polyhydroxyalkanoates (PHA) by activated sludge treating municipal wastewater: effect of $\mathrm{pH}$, sludge retention time (SRT), and acetate concentration in influent. Water Res 37:3602-3611

de Lourdes Tirado Montiel M, Tyagi RD, Valero JR (2001) Wastewater treatment sludge as a raw material for the production of Bacillus thuringiensis based biopesticides. Water Res 35(16):3807-3816

Foladori P, Andreottola G, Ziglio G (2010) Sludge reduction technologies in wastewater treatment plants. IWA Publishing, London

Jafari V, Labafzadeh SR, Jeihanipour A, Karimi K, Taherzadeh MJ (2011) Construction and demolition lignocellulosic wastes to bioethanol. Renew Energy 36:2771-2775

Jeihanipour A, Bashiri R (2015) Perspective of biofuels from wastes. In: Karimi K (ed) Lignocellulose-based bioproducts. Springer, Zurich, pp 37-83

Jeihanipour A, Taherzadeh MJ (2009) Ethanol production from cotton-based waste textiles. Bioresour Technol 100:1007-1010

Jeihanipour A, Karimi K, Niklasson C, Taherzadeh MJ (2010) A novel process for ethanol or biogas production from cellulose in blended-fibers waste textiles. Waste Manage 30:2504-2509

Kelessidis A, Stasinakis AS (2012) Comparative study of the methods used for treatment and final disposal of sewage sludge in European countries. Waste Manage 32:1186-1195

Kobayashi G, Eto K, Tashiro Y, Okubo K, Sonomoto K, Ishizaki A (2005) Utilization of excess sludge by acetone-butanol-ethanol fermentation employing Clostridium saccharoperbutylacetonicum N1-4 (ATCC 13564). J Biosci Bioeng 99:517-519

Ma K, Maeda T, You H, Shirai Y (2014) Open fermentative production of 1-lactic acid with high optical purity by thermophilic Bacillus coagulans using excess sludge as nutrient. Bioresour Technol 151:28-35

Macrelli S, Mogensen J, Zacchi G (2012) Techno-economic evaluation of 2 nd generation bioethanol production from sugar cane bagasse and leaves integrated with the sugar-based ethanol process. Biotechnol Biofuels 5:1-18
Manara P, Zabaniotou A (2012) Towards sewage sludge based biofuels via thermochemical conversion-a review. Renew Sustain Energy Rev 16:2566-2582

Marchioretto M, Bruning H, Loan N, Rulkens W (2002) Heavy metals extraction from anaerobically digested sludge. Water Sci Technol 46:1-8

Motlagh AM, Goel RK (2014) Chapter 16-sustainability of activated sludge processes. In: Ahuja S (ed) Water reclamation and sustainability. Elsevier, Boston, pp 391-414

Pham T, Brar SK, Tyagi R, Surampalli R (2009) Ultrasonication of wastewater sludge-consequences on biodegradability and flowability. J Hazard Mater 163:891-898

Philpott CC, Rashford J, Yamaguchi-Iwai Y, Rouault TA, Dancis A, Klausner RD (1998) Cell-cycle arrest and inhibition of G1 cyclin translation by iron in AFT1-1up yeast. EMBO J 17:5026-5036

Pilli S, Bhunia P, Yan S, LeBlanc R, Tyagi R, Surampalli R (2011) Ultrasonic pretreatment of sludge: a review. Ultrason Sonochem 18:1-18

Rebah FB, Prévost D, Yezza A, Tyagi R (2007) Agro-industrial waste materials and wastewater sludge for rhizobial inoculant production: a review. Bioresour Technol 98:3535-3546

Rice EW, Bridgewater L, American Public Health Association (2012) Standard methods for the examination of water and wastewater. American Public Health Association, Washington DC

Roy MM, Dutta A, Corscadden K, Havard P, Dickie L (2011) Review of biosolids management options and co-incineration of a biosolid-derived fuel. Waste Manage 31:2228-2235

Sheikh MMI, Kim C-H, Lee J-Y, Kim S-H, Kim G-C, Shim S-W, Kim J-W (2013) Production of bioethanol from waste money bills-a new cellulosic material for biofuels. Food Bioprod Process 91:60-65

Siddiquee MN, Rohani S (2011) Lipid extraction and biodiesel production from municipal sewage sludges: a review. Renew Sustain Energy Rev 15:1067-1072

Soccol CR, de Souza Vandenberghe LP, Medeiros ABP, Karp SG, Buckeridge M, Ramos LP, Pitarelo AP, Ferreira-Leitão V, Gottschalk LMF, Ferrara MA, da Silva Bon EP, de Moraes LMP, de Amorim Araújo J, Torres FAG (2010) Bioethanol from lignocelluloses: status and perspectives in Brazil. Bioresour Technol 101(13):4820-4825

Tambone F, Scaglia B, D'Imporzano G, Schievano A, Orzi V, Salati S, Adani F (2010) Assessing amendment and fertilizing properties of digestates from anaerobic digestion through a comparative study with digested sludge and compost. Chemosphere 81:577-583

Tchobanoglous G, Burton FL, Stensel HD (2003) Wastewater engineering: treatment and reuse. McGraw-Hill, Boston

Ting C, Lee D (2007) Production of hydrogen and methane from wastewater sludge using anaerobic fermentation. Int J Hydrogen Energy 32:677-682

Tyagi VK, Lo S-L (2013) Sludge: a waste or renewable source for energy and resources recovery? Renew Sustain Energy Rev $25: 708-728$

Vidyarthi A, Tyagi R, Valero J, Surampalli R (2002) Studies on the production of $B$. thuringiensis based biopesticides using wastewater sludge as a raw material. Water Res 36:4850-4860

Wang J, Chen C (2006) Biosorption of heavy metals by Saccharomyces cerevisiae: a review. Biotechnol Adv 24:427-451

Wang Q, Jiang G, Ye L, Yuan Z (2014) Enhancing methane production from waste activated sludge using combined free nitrous acid and heat pre-treatment. Water Res 63:71-80

Wilson CA, Novak JT (2009) Hydrolysis of macromolecular components of primary and secondary wastewater sludge by thermal hydrolytic pretreatment. Water Res 43:4489-4498 
Xiang L, Chan LC, Wong JWC (2000) Removal of heavy metals from anaerobically digested sewage sludge by isolated indigenous iron-oxidizing bacteria. Chemosphere 41:283-287

Yan P, Ji F, Wang J, Fan J, Guan W, Chen Q (2013) Evaluation of sludge reduction and carbon source recovery from excess sludge by the advanced sludge reduction, inorganic solids separation, Phosphorus recovery, and Enhanced nutrient Removal (SIPER) wastewater treatment process. Bioresour Technol 150:344-351
Yezza A, Tyagi R, Valéro J, Surampalli R (2005) Production of Bacillus thuringiensis based biopesticides in batch and fed batch cultures using wastewater sludge as a raw material. J Chem Technol Biotechnol 80:502-510

Zhang L, Xu C, Champagne P, Mabee W (2014) Overview of current biological and thermo-chemical treatment technologies for sustainable sludge management. Waste Manage Res 32:586-600 